\title{
THE LIFE PARTNER AND THE LIFE SATISFACTION OF THE ENTREPRENEUR
}

\section{El Shoubaki, A., Stephan, M.}

The life satisfaction of entrepreneurs is a subject of increasing importance. Research shows that entrepreneurs are more satisfied with their jobs when compared to wage earners. However, it remains poorly understood how satisfied entrepreneurs are with their lives. We argue that the family can contribute largely to how individuals feel about their lives. In particular, research suggests that the life partner influences the individual's life satisfaction differently depending on their occupation (employed or self-employed). Thus, in this paper we investigate the effect of life partners on the life satisfaction of entrepreneurs. To do so, we use arguments from the family embeddedness perspective on entrepreneurship and test them using data from the 2016 cohort of the German Socio-economic Panel Study (SOEP) and regression models. We find that the life partner contributes positively to the life satisfaction of entrepreneurs and wage earners. This effect is greater for entrepreneurs without employees as compared to entrepreneurs with employees. These results contribute to the understanding of an under researched outcome of entrepreneurship which is the life satisfaction of entrepreneurs.

Keywords: life satisfaction, entrepreneurship, self-employment, life partner, family JEL Classification: L26, I30

\section{Introduction}

How satisfied individuals are with their lives is an important economic variable indicative of social progress (Andersson, 2008). Supranational organizations, such as the OECD, seek to measure socioeconomic progress with initiatives which aim to understand how individuals feel about their lives (i.e. how's life?). To everyone, being happy is a compelling idea; a feeling of life satisfaction is important for human functioning (Ryff, 2017). It has a positive effect on individuals' productivity (Lyubomirsky et al., 2005) including that of entrepreneurs (e.g. Wincent et al. 2008). Moreover, as much as policymakers are departing from traditional economic measures, with initiatives such as 'beyond GDP' (European Commission, 2016), so is research in entrepreneurship increasingly calling for novel insights beyond financial measures (Shepherd, 2015). Satisfaction with life is not a financial question, yet it is still a measure of success (Wach et 
al., 2016). The life satisfaction of entrepreneurs is important to better shed light on the entrepreneurial process and ultimately to help sustain the economic and social benefits of entrepreneurship. Thus, understanding what drives the life satisfaction of entrepreneurs is a crucial line of inquiry, equally interesting to policymakers, researchers, and entrepreneurs. In this present paper, we use the terms entrepreneur and self-employed interchangeably. ${ }^{1}$

The concept of life satisfaction is multifaceted and work is just one aspect of it (Binder \& Coad, 2013). It is noteworthy though, that work seems central to the lives of entrepreneurs (Loewe et al., 2015). There is strong evidence that entrepreneurs are more satisfied with their work when compared to employed individuals (Blanchflower, 2004; Blanchflower et al., 2001; Blanchflower \& Oswald, 1998; Millán et al., 2013; Van der Zwan et al., 2018); yet, drivers of the life satisfaction of entrepreneurs remain less clear (Dolan et al., 2008; Binder \& Coad, 2016). Entrepreneurship, as a work type, can presents a trade-off (Stephan, 2018). On the one hand, being one's own boss provides greater control over the work situation through increased schedule flexibility and freedom that enable better work-life balance which in turn enhances life satisfaction (Benz \& Frey, 2008; Loscocco, 1997; Parasuraman \& Simmers, 2001). However, it is also associated with heavy workload and financial uncertainty leading to higher levels of stress (Dahl et al., 2010; Cardon \& Patel, 2015; Patzelt \& Shepherd, 2011). Self-employment can cause increased work-family conflict (Blanchflower, 2004); imbalance between the different domains of life leads to conflicts and is detrimental to the life satisfaction of individuals (Parasuraman \& Simmers, 2001). The self-employed can be less satisfied with their leisure, which is one aspect of their life satisfaction (Van der Zwan, 2018). Moreover, self-employment can affect the health of the entrepreneur and those close to him or her such as the life partner (Dahl et al., 2010). Acknowledging the complexity of the concept of life satisfaction, in this study, we adopt a socialized view of the entrepreneur and focus on their immediate social environment i.e. a family condition - the presence of a life-partner. Put simply, we will answer the question: do life-partners increase entrepreneurs' life satisfaction?

To answer this question, we use arguments from the family embeddedness perspective on entrepreneurship (Aldrich \& Cliff, 2003), data of some 1300 entrepreneurs from the 2016 cohort of the German Socio-economic Panel Data (SOEP), and regression models.

This study contributes to research and to practice. To research, the findings provide a nuanced view the life partner's contribution to the life satisfaction of the entrepreneur because we distinguish between different types of self-employed individuals (with and without employees) and compare them to wage earners. In practical terms, the findings can help policy-makers in understanding the factors affecting how people feel about their lives. It may be particularly useful to take into account the life partner in programs and policies supporting and promoting entrepreneurship and work family balance.

\footnotetext{
${ }^{1}$ Many authors can consider the terms different but you may refer to Carter (2011) to learn better about these point of views.
} 
We start the paper by presenting the theoretical arguments. Next, we disclose the methodology and the results. Lastly, we discuss the results and present our contributions.

\section{Literature Review}

\subsection{Family embeddedness in entrepreneurship}

The organization of economic utility is central to the family (Becker, 1991); yet, theorizing the role of the family in the entrepreneurial process is an ongoing research challenge (Heck et al., 2008). A century ago, all businesses were family businesses but social change, especially the increase in employment, led to consider that the two social institutions are separate units, and so research treated each independently (Stafford et al., 1999). In reality, the family and the business remain two connected social institutions and treating them as such in research is a more realistic approach to studying entrepreneurship. The family embeddedness perspective on entrepreneurship addresses this issue head on (Aldrich \& Cliff, 2003).

Three decades ago, the systemic approach to entrepreneurship emerged and began to consider the substantial influence that family exerts on the firm (Hollander \& Elman, 1988). Aldrich and Cliff (2003) advanced the conversation on the "family embeddedness perspective" by studying entrepreneurship using a model of the interrelation among family system characteristics and venture creation processes and outcomes. Entrepreneurship research recognizes that entrepreneurs are embedded in various social relationships (Aldrich et al., 1986; Burt, 1992). Particularly, the family is the one social institution in which all entrepreneurs are embedded (Aldrich \& Cliff, 2003). The family system of entrepreneurs is made of the values, attitudes, norms, behaviors and resources shared among family members that influence the decision making of entrepreneurs (Rowe \& Hong, 2000).

The concept of family, from a structural view, rests on the assumption that family is constituted of biologically and legally tied individuals (Westhead \& Cowling, 1998). From a transactional view, the family is made of intimates sharing a history and a future and generating a sense of home and group identity (Westhead et al., 2002). Accordingly, the life-partner can be considered a family member disregarding the legal bond of the relationship. Family provides social support; that is, a form of goodwill, a product of social relations and a resource to aid action (Adler \& Kwon, 2002). On an aggregate level, social support seems beneficial to entrepreneurs (Stam et al., 2014).

The life partner, in particular, has a critical yet unexplored role in the life of the entrepreneur (Williams, 2012); he or she can influence the entrepreneur in non-visible ways (Gillis-Donovan \& Moynihan-Bradt, 1990; Rowe \& Hong, 2000). Entrepreneurs and their life partners share life goals and care for each other in different ways than with other family members (Brannon et al., 2013). And while entrepreneurship research focused on the role of the life partner in the venture, other roles are underexplored such as the 
wellbeing of the entrepreneur (Binder \& Coad, 2016). In this paper, we attempt to answer the question: do life-partners increase entrepreneurs' life satisfaction?

\subsection{Life satisfaction and the life partner}

Life satisfaction is a global evaluation of the individual's state of being or happiness (Benz \& Frey, 2008; Binder \& Coad, 2010; Coad \& Binder, 2014). It is determined by a number of factors including, but not limited to, individual characteristics (e.g. age, sex) and affect (e.g. moods and emotions); as well as environmental influences including job conditions (e.g. age, size, income) and family conditions (e.g. household income, marital status) (Clark et al., 2008; Diener, 2000; Stephan, 2018). In addition, the life satisfaction of an individual is likely to be a subjective indicator since it relies on self-assessments and reporting (Diener, 2000). Acknowledging the complexity of the concept of life satisfaction, in this study, we focus particularly on the immediate environment of the entrepreneur i.e. a family condition - the presence of a life-partner.

For wage earners, the life partner seems to have tangible influences on them. In labor economics, as "marriage surplus" refers to the benefits brought about to men consequent to marriage, such as increased wages; for women, an opposite consequence of marriage is evidenced in the labor market i.e. "marriage deficit" (Parker, 2009). Another marriage benefit concerns health - mental and physical health is strongly and positively associated to marriage (Gove, et al., 1983; Wilson \& Oswald, 2005). Also in the case of selfemployment, the life partner is important in terms of providing emotional or also instrumental support; whereby this emotional and financial cushion encourages the entrepreneur to be bolder in business (Parker, 2009; Simoes et al., 2016). Entrepreneurs and business owner-managers can have heavy workloads, and financial uncertainty, which results in financial difficulties, stress (Dahl et al., 2010; Cardon \& Patel, 2015; Patzelt \& Shepherd, 2011) and work-family conflicts (Blanchflower, 2004; Parasuraman \& Simmers, 2001). With such circumstances, the life-partner can provide many benefits. Moreover, the life partner can be very engaged in the life of the entrepreneur to the extent of enduring stress in similar extents. For example, one study found that individuals entering entrepreneurship are more likely to take psychotropics (drugs that affect the nervous system to alter mood, perceptions, thoughts and behaviors), when compared to individuals changing into other types of jobs, and so are their spouses when compared to other spouses whose partner is not entering entrepreneurship (Dahl et al., 2010). Empirical evidence on the life satisfaction of entrepreneurs portrays diverse results when controlling for the presence of the life partner. These findings range from non-significant effects on job satisfaction of entrepreneurs - which is one aspect of life satisfaction (e.g. Millán et al., 2013; Block \& Koellinger, 2009) - to non-significant effects on life satisfaction (Coad \& Binder (2014), or also positive effects (Van der Zwan et al., 2018). This last study finds that being married increased the life satisfaction of both, individuals switching from selfemployment to wage-employment and vice versa. Moreover, it seems that persons switching to self-employment witness a drop in satisfaction with leisure (Van der Zwan et al., 2018) probably due to the increase of stressors mentioned earlier e.g. increased 
workload and financial instability. Given that entrepreneurship exposes the individuals to increased stressors, the presence of a life partner becomes even more important than that with wage earners. Thus, we expect that:

H1: The effect of a life partner on the life satisfaction of an entrepreneur without employees, as compared to a wage-earner, is positive but higher.

The self-employed are not a homogeneous populace. The most distinct types are selfemployed without employees and the self-employed with employees (Burke \& Cowling, 2015). The literature suggests that they do not start from the same place. A study using a European sample shows that the self-employed with employees have higher degrees (Dvouletý, 2018; Millán et al., 2014), more work experience, are more likely to have working life partners (Dvouletý, 2018). Employees are resources taking a share work, which enables the self-employed to benefit from higher levels of autonomy (Binder \& Coad, 2016; Coad \& Binder, 2014). Employees can be compared to colleagues at work and both can bring benefits. However, for wage earners, the colleagues can be equal to them in terms of a firm's hierarchical structure, not directly or solely subordinate to them, and possibly not an aiding resource or an impeding one. The wage earners may not easily be able to influence or change this situation whereas the self-employed are more likely to have direct control over their employees; if these later do not meet minimum performance and conduct, the self-employed can be considered to be in a position to take direct measures to change this e.g. firing them. Thus, we expect that:

H2: The effect of a life partner on the life satisfaction of an entrepreneur with employees, as compared to a wage earner, is positive but less important.

\section{Materials and Methods}

\subsection{Data and sample}

To answer the research question "do life-partners increase entrepreneurs' life satisfaction?" we relied on data from the German Socio-Economic Panel Study (SOEP) conducted by the German Institute for Economic Research (DIW). The dataset includes information on a representative sample of German households regarding diverse aspects of life including household and work characteristics. About 11.000 German private households and over 20.000 members of these households are part of the panel survey. The samples of SOEP are multi-stage random samples and the participating households are chosen by random walk. The randomly chosen households are interviewed face to face based on a questionnaire that contains questions regarding different aspects of life (e.g. education, employment, health status, future plans). In the chosen households, one person is also asked to answer a questionnaire about the household itself (housing characteristics, inhabitants' characteristics, different kinds of income). For this study, we use data from the year 2016 amounting to a total observation of 1029 entrepreneurs. 


\subsection{Variables}

Our main variables of interest are as follows: the dependent variable is the individual's life satisfaction measured with one question regarding how satisfied the individual is with life in general. The answer to the question is based on an 11-point Likert scale where one indicates the lowest levels of satisfaction and eleven the highest. While we rely primarily on this variable as a dependent variable, we run extra analyses to confirm the results using the mean of eleven domains of satisfaction. These are measured similarly to life satisfaction.

Regarding independent variables, the presence of a life partner in explaining the life satisfaction of the entrepreneur is central to our paper as developed in the literature review. We created a dummy variable taking a value of one when the entrepreneur has a life partner. Other independent variables include the household income, the numbers of hours worked in the business, the perception of effort and over-commitment to work, and the number of children (Dolan et al., 2008). Household income contributes positively to life satisfaction for it provides increased financial security (Boes \& Winkelmann, 2010; Binder $\&$ Coad, 2014). The working hours per week are expected to negatively affect life satisfaction as the more hours spent working the less leisure and family time remains (Parasuraman et al.; 1989; Van der Zwan et al., 2018). We also add the perceived effort and overcommitment, which are measures in a leading job-stress model (Siegrist et al., 2004). It is assumed that an imbalance between perceived effort and reward in occupational life has a negative effect on life satisfaction (De Jonge et al., 2000) and so does the perceived overcommitment to work relate to life satisfaction (Siegrist et al., 2004). Children can be indicative of household responsibilities but also a source of lifesatisfaction (Van der Zwan et al., 2018). Some typical control variables are also included i.e. the age and the gender of the respondent and the sector of activity in which he or she is active.

Table 1 | Description of the variables

\begin{tabular}{|l|l|}
\hline \multicolumn{1}{|c|}{ Variables } & \multicolumn{1}{c|}{ Description } \\
\hline \multicolumn{2}{|c|}{ Dependent variable } \\
\hline Life satisfaction & $\begin{array}{l}\text { Overall Satisfaction of the self-employed measured on an eleven level Likert scale } \\
\text { (1= completely dissatisfied 11= completely satisfied) }\end{array}$ \\
\hline \multicolumn{1}{|c|}{ Independent variables } \\
\hline Life partner & $\begin{array}{l}\text { Relationship Status of the self-employed (1= in a relationship; 0= not in a } \\
\text { relationship) }\end{array}$ \\
\hline \multicolumn{1}{|c|}{ Controls } \\
\hline Effort & $\begin{array}{l}\text { Effort Level of the self-employed measured with three items on four level Likert } \\
\text { scale, 3= low effort level; 12= high effort level }\end{array}$ \\
\hline Overcommitment & $\begin{array}{l}\text { Level of perceived overcommitment to work by the self-employed measured with } \\
\text { the sum of six items on four level Likert scale (4= low overcommitment, 24= high } \\
\text { overcommitment) }\end{array}$ \\
\hline Working hours & Level of working hours per week \\
\hline
\end{tabular}




\begin{tabular}{|l|l|}
\hline $\begin{array}{l}\text { Household } \\
\text { Income }\end{array}$ & Level of household net income per month \\
\hline Conflict & Conflicts with partner that weigh upon the individual (1=yes; $0=$ no) \\
\hline Education & Number of years invested in education \\
\hline Gender & Gender of the individual $(1=$ male; $0=$ female) \\
\hline Age & Age of the individual (continuous variable) \\
\hline Children & Number of Children \\
\hline Industry & $\begin{array}{l}\text { The sector in which the self-employed is active is divided into ten main categories: } \\
\text { Agriculture, energy, manufacturing and industry, construction, trade, hospitality, } \\
\text { transport and communication, credit and insurance, business services and social } \\
\text { and health services (the reference group) }\end{array}$ \\
\hline
\end{tabular}

\subsection{Sample description}

From the SOEP dataset of 2016, we selected three samples, the first with only employed individuals (6938), the second with self-employed with employees (410) and the third with solo self-employed (613). The employed sample is made of $40 \%$ males, the sample of selfemployed with employees is $67 \%$ males, and the solo self-employed are $54 \%$ males. Apart from this variable, the differences in the descriptive statistics across the different categories are not extreme. $84 \%$ of the employed and solo self-employed have a life partner, against $90 \%$ for the self-employed with employees.

Table 2 | Descriptive statistics

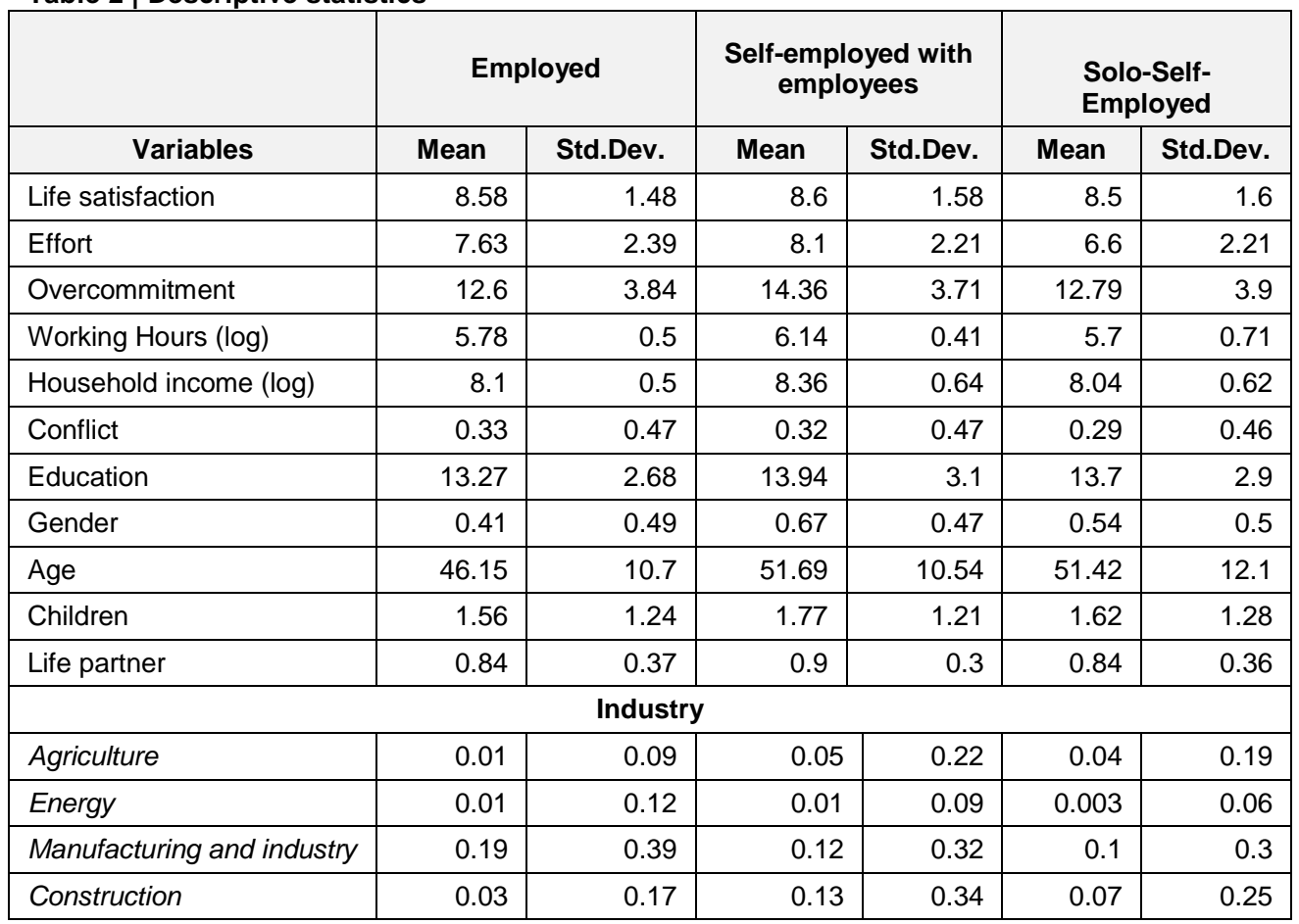




\begin{tabular}{|c|c|c|c|c|c|c|}
\hline Trade & 0.12 & 0.33 & 0.13 & 0.33 & 0.09 & 0.29 \\
\hline Hospitality & 0.03 & 0.17 & 0.07 & 0.26 & 0.02 & 0.13 \\
\hline $\begin{array}{l}\text { Transport } \\
\text { Communication }\end{array}$ & 0.06 & 0.23 & 0.02 & 0.13 & 0.02 & 0.14 \\
\hline Credit \& Insurance & 0.05 & 0.21 & 0.03 & 0.17 & 0.04 & 0.2 \\
\hline Business Services & 0.17 & 0.38 & 0.2 & 0.4 & 0.24 & 0.43 \\
\hline Health and Social Services & 0.33 & 0.47 & 0.25 & 0.44 & 0.38 & 0.49 \\
\hline Number of observations & \multicolumn{6}{|l|}{6938} \\
\hline
\end{tabular}

\subsection{Statistical procedure}

To examine the effect of the presence of the life partner on the life satisfaction of the entrepreneur, we estimate the following ordinary least square regression:

$$
Y_{i}=\beta_{2} \text { LifePartner }_{i}+\alpha_{x}^{\prime} \boldsymbol{X}_{\boldsymbol{i}}+\varepsilon_{i}
$$

where the dependent variable is the satisfaction level of the entrepreneur $i$, vector $\boldsymbol{X}_{i}$ includes all the other independent and control variables described above and the constant term, and $\varepsilon_{i}$ is the standard error term. The interpretation of the coefficients reads as follows: the effect of the presence of a life partner will be captured by $\beta$.

For robustness check, we run other models using other dependent variables. The results of these extra analyses support the current results.

\section{Results}

Table 3 exhibits the results of the regression models. Most importantly, regarding the lifepartner, we find a significant positive effect for the presence of a life-partner on the life satisfaction of the individual, where he or she is employed, self-employed with or without employees. The results do not support our hypotheses but most importantly there is significant and positive effect of the presence of the life partner. This effect is stronger for solo self-employed than for self-employed with employees. In addition, conflict with the life partner shows significant and negative effects across all types of employments, but this effect is particularly strong for the self-employed with employees. The negative effect of conflict does diminish from the positive effect the presence of a life partner, and the two variables do not exhibit collinearity.

Besides, the income of the household have a positive effect across all types of employments but particularly strong for the solo self-employed. The entrepreneur's age and perceived overcommitment to work have a negative effect on the life satisfaction of the respondents across all types of employment. The rest of the variables bare inconsistent effects across the different types of employments. Effort and working hours have negative effects almost only on the employed. Especially the industries, many of which are significant and negative for the employed. 
Table 3 | The regression models

\begin{tabular}{|c|c|c|c|c|c|c|}
\hline \multirow[b]{2}{*}{ Variables } & \multicolumn{2}{|c|}{ Employed } & \multicolumn{2}{|c|}{$\begin{array}{l}\text { Self-employed with } \\
\text { employees }\end{array}$} & \multicolumn{2}{|c|}{ Solo-Self-employed } \\
\hline & Coef. & $\begin{array}{l}\text { Std. } \\
\text { error }\end{array}$ & Coef. & $\begin{array}{l}\text { Std. } \\
\text { error }\end{array}$ & Coef. & Std. error \\
\hline Effort & $-0.022^{\star \star}$ & 0.009 & $0.070^{*}$ & 0.041 & -0.005 & 0.040 \\
\hline Overcommitment & $-0.072^{* * *}$ & 0.006 & $-0.122^{* * *}$ & 0.032 & $-0.077^{* * *}$ & 0.021 \\
\hline Working Hours & $0.153^{* * *}$ & 0.042 & 0.185 & 0.266 & 0.138 & 0.095 \\
\hline Household income & $0.410^{\star \star \star}$ & 0.042 & $0.247^{*}$ & 0.135 & $0.726^{\star \star \star}$ & 0.110 \\
\hline Conflict & $-0.305^{* * *}$ & 0.037 & $-0.836^{* * *}$ & 0.175 & $-0.303^{* *}$ & 0.137 \\
\hline Education & $0.017^{* *}$ & 0.007 & 0.029 & 0.026 & -0.034 & 0.024 \\
\hline Gender & -0.012 & 0.039 & 0.026 & 0.182 & $-0.242^{*}$ & 0.140 \\
\hline Age & $-0.016^{* * *}$ & 0.002 & $-0.021^{* * *}$ & 0.007 & $-0.017^{* * *}$ & 0.005 \\
\hline Children & 0.013 & 0.016 & -0.027 & 0.061 & 0.007 & 0.052 \\
\hline Life partner & $0.523^{* * *}$ & 0.059 & $0.489^{\star \star}$ & 0.247 & $0.508^{* *}$ & 0.207 \\
\hline \multicolumn{7}{|c|}{ Industry } \\
\hline Agriculture & -0.031 & 0.222 & -0.415 & 0.451 & -0.426 & 0.381 \\
\hline Energy & $-0.528^{* * *}$ & 0.158 & $1.098^{\star \star}$ & 0.560 & $-0.575^{\star * *}$ & 0.215 \\
\hline Manufacturing and industry & $-0.130^{* *}$ & 0.050 & 0.093 & 0.273 & -0.189 & 0.215 \\
\hline Construction & -0.034 & 0.098 & 0.347 & 0.284 & -0.110 & 0.295 \\
\hline Trade & $-0.163^{\star *}$ & 0.060 & 0.020 & 0.282 & -0.230 & 0.229 \\
\hline Hospitality & 0.049 & 0.110 & -0.079 & 0.376 & -0.625 & 0.461 \\
\hline Transport \& communication & $-0.342^{* * *}$ & 0.079 & -0.078 & 0.268 & -0.440 & 0.363 \\
\hline Credit \& Insurance & 0.046 & 0.077 & 0.081 & 0.406 & -0.339 & 0.306 \\
\hline Business Services & $-0.172^{* \star \star}$ & 0.050 & 0.154 & 0.236 & -0.206 & 0.167 \\
\hline Constant & 5.710 & 0.357 & 7.069 & 1.948 & 4.195 & 0.924 \\
\hline Number of observations & 6938 & & 410 & & 613 & \\
\hline $\mathrm{F}$ & $35.75^{\star \star \star}$ & & $3.90^{* \star *}$ & & $10.38^{\star \star \star}$ & \\
\hline R squared & 0.102 & & 0.1598 & & 0.1725 & \\
\hline
\end{tabular}

Note: ${ }^{* *}-p<0.01,{ }^{* *}-p<0.05,{ }^{*}-p<0.1$

\section{Discussion and Conclusion}

This study examined the effect of the presence of the life partner on the life satisfaction of entrepreneurs. Prior research on life satisfaction of entrepreneurs focused on job satisfaction. There is established evidence that self-employed individuals are more satisfied with their jobs than wage earners (Van der Zwan et al., 2018; Blanchflower, 2004, 2000; Blanchflower et al., 2001). However, there is more to life satisfaction than job satisfaction and we still know little about it (Stephan, 2018; Dolan et al., 2008). This study 
addresses this gap in the literature while focusing on the family embeddedness, particularly, the effect of the life-partner.

To do so, we relied on regression models and a German dataset (SOEP) using data of selfemployed and employed (as a reference group) individuals including individual-, household- and firm-level variables. We argued that entrepreneurs are embedded in families and through this embeddedness they receive social support (Aldrich \& Cliff, 2003). Particularly, the life partner is a critical person in the entrepreneur's life (Williams, 2012). He or she influences the entrepreneur in non-visible ways (Gillis-Donovan \& Moynihan-Bradt, 1990; Bird \& Zellweger, 2018). Moreover, couples share life goals and care for each other in different ways than they do with other family members (Brannon et al., 2013; Bird \& Zellweger, 2018). The findings of our study mainly show that having a life partner positively affects the life satisfaction of the entrepreneur, even in the event of conflicts. This effect is not particular to entrepreneurs as compared to wage earners. Still, some new evidence is brought to light.

Prior studies did not focus on the relationship status of the entrepreneur per se when studying the life satisfaction of entrepreneurs. However, when contrasted to the most comparable studies, our results align with some extant findings (e.g. Van der Zwan et al., 2018) but not with the rest of studies that examined life satisfaction of the entrepreneur (Coad \& Binder, 2014) or some domain of life satisfaction such as job satisfaction (e.g. Millan et al., 2013; Block \& Koellinger, 2009). While the different results regarding the studies focusing on work satisfaction can be due to measuring a very specific domain of satisfaction, the results concerning life satisfaction are less evident - perhaps the diverging findings are due to the different testing methods and variables. Regarding the convergent results, in their study, examining how individuals feel about their life when they switch from wage-employment to self-employment and vice versa, Van der Zwan et al. (2018) find that being married increased life satisfaction in all cases. Our results are also in accordance with research on employees concluding that marital status is a strong predictor of wellbeing (Gove et al., 1983; Wilson \& Oswald, 2005) and the logics of "marriage surplus" (Parker, 2009). However, we extend extant literature by providing evidence for the self-employed (with and without employees) by comparing them to wage earners. The effect on the self-employed with employees is the smallest probably because having more employees to rely on can be comforting for the entrepreneur and increases their autonomy (Binder \& Coad, 2016; Binder \& Coad, 2014)

Additionally, our results show that despite the presence of conflicts between the life partners, which bares negative effects of the life satisfaction of both the entrepreneurs and wage earners, the effect of the presence of a life partner is still positive. This is probably because a life partner can be a source of financial, material and emotional support (Simoes et al., 2016). Also linked to the life partner, our results show the positive effect of the household income. The household income most likely includes the income of the life partner and thereby, represents the financial support of the life partner (Fletcher, 2010). 
Regarding the rest of variables, overcommitment affects negatively the different categories of employment aligned with previous results (De Jonge et al., 2000). However, we find that the employees stand out from the self-employed regarding the negative effect of their perception of effort and working hours on their life satisfaction. This probably aligns with the findings that self-employed are more satisfied with their work (e.g. Van der Zwan et al., 2018). We also found that age bares a negative effect on life satisfaction, which is a common observation in the literature (Witt et al., 1980; Gerdtham et al., 2001). Unlike ex As such, our study contributes to research on life satisfaction and to family embeddedness in entrepreneurship. Regarding the literature on life satisfaction, we provide evidence that the presence of the life partner increases the life satisfaction of entrepreneurs even in the event of conflict. To deepen the understanding of this finding, we invite future research to look into the processes involved in the social support provided by the life partner. For example, the way the life partners make decisions such as in distributing tasks in the household and outside. It is also noteworthy to examine the nuances in the processes, as in between cohabiting and married couples. Another line of investigation can be looking into the links between the different types of satisfaction (e.g. health, job, family, social life). Concerning the literature on family embeddedness in entrepreneurship, we demonstrate that family matters to the life satisfaction of entrepreneurs and employees similarly. If research is criticizing entrepreneurship for its failed financial promises (Shepherd, 2015), acknowledging the omnipresent role of the family and examining outcomes such as life satisfaction is then more urgent than ever.

Practical contributions pertain to policymakers. Supranational organizations such as OECD are increasingly interested in understanding the determinants of life satisfaction, and they are traditionally and continuously interested in promoting entrepreneurship (Wong et al., 2005). Thus, our results are useful to policymakers in designing programs that are better fit to entrepreneurs, precisely, programs that take into account the life partner. Clearly, entrepreneurs are embedded in their social network and their families. Our results provide evidence that the life partner, in particular, is crucial to the entrepreneur just as it is to the employee.

This study is also subject to a number of limitations. The results are to be taken with caution; causality and generalizability are not inferred. First, this study uses cross-sectional data; thus we only capture a static view of the influence of the life partner on the life satisfaction of the entrepreneur. Future studies are encouraged to test the question longitudinally. Second, the data represents only German households, which may have specificities. This way, the results are not generalizable. However, noteworthy is that extant empirical evidence draw largely from the same German dataset (SOEP) (e.g. Van der Zwan et al., 2018; Coad \& Binder, 2014; Block \& Koellinger, 2009). Third, the measures of life satisfaction are subjective self-reports. Perhaps adding reports from other parties (e.g. the life partner or close friends) or also from observations could yield stronger findings. Unlike extant findings, we find no effect of children, no effect of education on the self-employed. 


\section{References}

Adler, P. S., \& Kwon, S.-W. (2002). Social capital: Prospects for a new concept. Academy of Management Review, 27(1), 17-40.

Aldrich, H. E., \& Cliff, J. E. (2003). The pervasive effects of family on entrepreneurship: toward a family embeddedness perspective. Journal of Business Venturing, 18(5), 573-596.

Aldrich, H., Zimmer, C., \& Jones, T. (1986). Small business still speaks with the same voice: a replication of 'the voice of small business and the politics of survival'. The Sociological Review, 34(2), 335-356.

Andersson, P. (2008). Happiness and health: Well-being among the self-employed. Journal of Socio-Economics, 37(1), 213-236.

Benz, M., \& Frey, B. S. (2008). Being independent is a great thing: Subjective evaluations of self-employment and hierarchy. Economica, 75(298), 362-383.

Binder, M., \& Coad, A. (2010). An examination of the dynamics of well-being and life events using vector autoregressions. Journal of Economic Behavior and Organization, 76(2), 352-371.

Binder, M., \& Coad, A. (2013). Life satisfaction and self-employment: A matching approach. Small Business Economics, 40(4), 1009-1033.

Binder, M., \& Coad, A. (2016). How satisfied are the self-employed? A life domain view. Journal of Happiness Studies, 17(4), 1409-1433.

Bird, M., \& Zellweger, T. (2018). Relational embeddedness and firm growth:Comparing spousal and sibling entrepreneurs. Organization Science, 29(2), 264-283.

Blanchflower, D. G. (1998). What Makes an Entrepreneur? Journal of Labor Economics, 16(1), 26-60.

Blanchflower, D. G. (2004). Self-Employment: More may not be better. (No. w10286). National Bureau of Economic Research.

Blanchflower, D. G., Oswald, A. J., \& Stutzer, A. (2001). Latent entrepreneurship across nations. European Economic Review, 45(4-6), 680-691.

Block, J., \& Koellinger, P. (2009). I can't get no satisfaction - Necessity entrepreneurship and procedural utility. Kyklos, 62(2), 191-209.

Boes, S., \& Winkelmann, R.(2010). The Effect of Income on General Life Satisfaction. Social Indicators Research, 95, 111-128.

Brannon, D. L., Wiklund J., \& Haynie, J. M. (2013). The varying effects of family relationships in entrepreneurial teams. Entrepreneurship Theory and Practice, 37(1), 107-132.

Burke, A., \& Cowling, M. (2015). The use and value of freelancers: The perspective of managers. International Review of Entrepreneurship, 13(1), 7-20.

Burt, R. (1998). The gender of social capital. Rationality and Society, 10(1), 5-46.

Cardon, M. S., \& Patel, P. C. (2015). Is Stress Worth it? Stress-Related Health and Wealth Trade-Offs for Entrepreneurs. Applied Psychology, 64(2), 379-420. 
Carter, S. (2011). The rewards of entrepreneurship: Exploring the incomes, wealth and economic well-being of entrepreneurial households. Entrepreneurship Theory and Practice, 35(1), 39-55.

Clark, A. E., Diener, E., Georgellis, Y., \& Lucas, R. E. (2008). Lags and leads in life satisfaction: A test of the baseline hypothesis. Economic Journal, 118(529), 222244.

Coad, A., \& Binder, M. (2014). Causal linkages between work and life satisfaction and their determinants in a structural VAR approach. Economics Letters, 124(2), 263268.

Dahl, M. S., Nielsen, J., \& Mojtabai, R. (2010). The effects of becoming an entrepreneur on the use of psychotropics among entrepreneurs and their spouses. Scandinavian Journal of Public Health, 38(8), 857-863.

De Jonge, J., Bosma, H., Peter, R., Siegrist, J. (2000). Job Strain, effort-reward imbalance and employee well-being: a large-scale cross-sectional study. Social Science \& Medicine, 50, 1317-1327.

Diener, E. (2000). Subjective well-being: The science of happiness and a proposal for a national index. American Psychologist, 55(1), 34-43.

Dolan, P., Peasgood, T., \& White, M. (2008). Do we really know what makes us happy? A review of the economic literature on the factors associated with subjective wellbeing. Journal of Economic Psychology, 29(1), 94-122.

Dvouletý, O. (2018). Determinants of Self-employment With and Without Employees: Empirical Findings from Europe. International Review of Entrepreneurship, (16)3.

European Commission (2016). Beyond GDP: Measuring progress, true wealth, and wellbeing. Retrieved September 25, 2016, from http://ec.europa.eu/environment/beyond_gdp/index_en.html

Fletcher, D. (2010). "Life-making or risk taking"? Co-preneurship and family business start-ups. International Small Business Journal, 28(5), 452-469.

Gerdtham, U. G., \& Johannesson, M. (2001). The relationship between happiness, health, and socio-economic factors: results based on Swedish microdata. The Journal of Socio-Economics, 30(6), 553-557.

Gillis-Donovan, J., \& Moynihan-Bradt, C. (1990). The power of invisible women in the family business. Family Business Review, 3(2), 153-167.

Gove, W. R., Hughes, M., \& Style, C. B. (1983). Does Marriage Have Positive Effects on the Psychological Well-Being of the Individual? Journal of Health and Social Behavior, 24(2), 122-131.

Heck, R. K. Z., Hoy, F., Poutziouris, P. Z., \& Steier, L. P. (2008). Emerging Paths of Family Entrepreneurship Research. Journal of Small Business Management, 46(3), 317-330.

Hollander. B., \& Elman, N. (1988). Family-owned business: An emerging field of inquiry. Family Business Review, 1(2). 145-164. 
Loewe, N., Araya-Castillo, L., Thieme, C., \& Batista-Foguet, J. M. (2015). Selfemployment as a moderator between work and life satisfaction. Academia-Revista Latinoamericana de Administracion, 28(2), 213-226.

Loscocco, K. A. (1997).Work-family linkages among self-employed women and men. Journal of Vocational Behavior, 50, 204-226.

Lyubomirsky, S., King, L., \& Diener, E. (2005). The benefits of frequent positive affect: Does happiness lead to success? Psychological Bulletin, 131(6), 803-855.

Millán, A., Millán, J. M., Román, C., \& Van Stel, A. (2014). Determinants of the ownaccount worker's decision to hire employees: A review. International Review of Entrepreneurship, 13(2), 129-142.

Millán, J. M., Hessels, J., Thurik, R., \& Aguado, R. (2013). Determinants of job satisfaction: A European comparison of self-employed and paid employees. Small Business Economics, 40(3), 651-670.

Parasuraman, S., Greenhaus, J. H., Rabinowitz, S., Bedeian, A. G., \& Mossholder, K. W. (1989). Work and Family Variables As Mediators of the Relationship Between Wives' Employment and Husbands' Well-Being. Academy of Management Journal, 32(1), 185-201.

Parasuraman, S., \& Simmers, C. (2001). Type of employment, work-family conflict and well- being: A comparative study. Journal of Organizational Behavior, 22(5), 551-568.

Parker, S. (2009). The Economics of Entrepreneurship. Cambridge University Press. Patzelt, H., \& Shepherd, D. A. (2011). Negative emotions of an entrepreneurial career: Self- employment and regulatory coping behaviors. Journal of Business Venturing, 26(2), 226-238.

Rowe, B. R., \& Hong, G. S. (2000). The role of wives in family businesses: The paid and unpaid work of women. Family Business Review, 13(1), 1-13.

Ryff, C. D. (2017). Eudaimonic well-being, inequality, and health: Recent findings and future directions. International Review of Economics, 64(2), 159-178.

Shepherd, D. A. (2015). Party On! A call for entrepreneurship research that is more interactive, activity based, cognitively hot, compassionate, and prosocial. Journal of Business Venturing, 30(4), 489-507.

Siegrist, J., Starke, D., Chandola, T., Godin, I., Mamot, M., Niedhammer, I., Peter, R. (2004). The measurement of effort-reward imbalance at work: European comparisons. Social Science \& Medicine, 58, 1483 -1499.

Simoes, N., Crespo, N., \& Moreira, S. B. (2016). Individual determinants of selfemployment entry: What do we really know? Journal of Economic Surveys, 30(4), 783-806.

Stafford, K., Duncan, K. A., Danes, S., Winter, M. (1999). A research model of sustainable family businesses. Family Business Review, 7(3), 197-208.

Stam, W., Arzlanian, S., \& Elfring, T. (2014). Social capital of entrepreneurs and small firm performance: A meta-analysis of contextual and methodological moderators. Journal of Business Venturing, 29(1), 152-173. 
Stephan, U. (2018). Entrepreneurs' Mental Health and Well-Being: A Review and Research Agenda. Academy of Management Perspectives, 32(3), 290-322.

Van der Zwan, P., Hessels, J., \& Rietveld, C. A. (2018). Self-employment and satisfaction with life, work, and leisure. Journal of Economic Psychology, 64, 64-88.

Wach, D., Stephan, U., \& Gorgievski, M. (2016). More than money: Developing an integrative multi-factorial measure of entrepreneurial success. International Small Business Journal, 34(8), 1098-1121.

Westhead, P., \& Cowling, M. (1998). Family firm research: The need for a methodological rethink. Entrepreneurship Theory and Practice, 23(1), 31-33.

Westhead, P., Howorth, C., \& Cowling, M. (2002). Ownership and management issues in first generation and multi-generation family firms. Entrepreneurship and Regional Development, 14(3), 247-269.

Williams, D. K. (2012). The entrepreneurial spouse: The vital role of the significant other. Forbes, August 2012. Retrieved January 15, 2018 from https://www.forbes.com/sites/davidkwilliams/2012/08/19/the-entrepreneurialspouse-the-vital-role-of-the-significant-other/.

Wilson, C., \& Oswald, A. J. (2005). How does marriage affect physical and psychological health? A survey of the longitudinal evidence. The Warwick Economics Research Paper Series (TWERPS) 728, Coventry, UK: University of Warwick.

Wincent, J., Örtqvist, D., \& Drnovsek, M. (2008). The entrepreneur's role stressors and proclivity for a venture withdrawal. Scandinavian Journal of Management, 24, $232-246$.

Witt, D. D., Lowe, G. D., Peek, C. W., \& Curry, E. W. (1980). The changing association between age and happiness: Emerging trend or methodological artifact? Social Forces, 58(4), 1302-1307.

Wong, P. K., Ho, Y. P., \& Autio, E. (2005). Entrepreneurship, innovation and economic growth: Evidence from GEM data. Small Business Economics, 24(3), 335-350. 


\section{Authors}

\section{Aliaa El Shoubaki}

Montpellier Business School

2300 av. des Moulins, F34185, Montpellier, France

a.elshoubaki@montpellier-bs.com

\section{Meike Stephan}

Chair for SME Management and Entrepreneurship

University of Siegen

Unteres Schloss III, 57072 Siegen, Germany

meike.stephan@uni-siegen.de 